\title{
Normalized Difference Vegetation Index (NDVI) analysis for vegetation cover in Leuser Ecosystem area, Sumatra, Indonesia
}

\author{
ADISTI PERMATASARI PUTRI HARTOYO ${ }^{1, \boldsymbol{v}}$, ARZYANA SUNKAR ${ }^{2}$, RAHMATULLOH RAMADANI, $^{1}$, \\ SYAHLAN FALUTHI ${ }^{2}$, SYAFITRI HIDAYATI ${ }^{2}$ \\ ${ }^{1}$ Department of Silviculture, Faculty of Forestry and Environment, Institut Pertanian Bogor. Jl. Lingkar Akademik, Dramaga, Bogor 16680, West Java, \\ Indonesia. Tel./fax.: +62-251-862-6806, `email: adistipermatasari@apps.ipb.ac.id \\ ${ }^{2}$ Department of Forest Conservation and Ecotourism, Faculty of Forestry and Environment, Institut Pertanian Bogor. Jl. Lingkar Akademik, Dramaga, \\ Bogor 16680, West Java, Indonesia. Tel.: +62-251-862-1677, Fax.: +62-251-862-1256, email: arzyana@yahoo.com, arzyanas@gmail.com
}

Manuscript received: 10 December 2020. Revision accepted: 4 February 2021.

\begin{abstract}
Hartoyo APP, Sunkar A, Ramadani R, Faluthi S, Hidayati S. 2021. Normalized Difference Vegetation Index (NDVI) analysis for vegetation cover in Leuser Ecosystem area, Sumatra, Indonesia. Biodiversitas 22: 1160-1171. About 2 Mha of 24.3 Mha degraded area in Indonesia is inside conservation area. The Leuser Ecosystem Area (LEA) is the largest conservation area in Malesian forest that plays essential role in biodiversity and ecosystem services conservation efforts. It is the last habitat on earth where Sumatran tigers, elephants, orangutans, and rhinoceros are found together. However, LEA faces many threats, such as infrastructure development, and industrial palm oil plantation. Additionally, vegetation cover data as an approach to monitor forest cover changes in LEA is still lacking and baseline data regarding composition, structure as well as vegetation diversity in LEA is very limited. The objectives of this study were to analyze vegetation cover using Normalized Difference Vegetation Index (NDVI) in LEA and its relation to agroforestry structure, composition and diversity in Agusen Village, Gayo Lues District and Alur Durin Village, East Aceh District, Aceh Province belonging to LEA. Based on the NDVI analysis, the largest area in LEA belonged to class 5, meaning that the most area in LEA was dominated by high dense vegetation $(1,870,116.40 \mathrm{ha})$. The average accuracy and standard error of NDVI analysis were $83.33 \%$ and 2.62. LEA is an effective buffer for maintaining forest ecosystems and increasing the local communities' welfare through agroforestry system. Agroforestry structures in agroforestry practices, both in Agusen Village and Alur Durin Village did not reflect reverse-J curve, meaning that enrichment planting for increasing numbers of individual and species was necessary. Management of agroforestry system depends on the landowners or managers and their selection of shade tree species with high economic value with market demand such as C. arabica, T. cacao with A. moluccanus, L. leucocephala, H. brasiliensis, D. zibethinus, etc. Trees that produce non-timber products are also an alternative way for conservation strategy and sustainable utilization.
\end{abstract}

Keywords: Aceh Province, forest ecosystem, Landsat 8, plant community, remote sensing

\section{INTRODUCTION}

Indonesia is rising to the third position in terms of the largest tropical forest with mega-biodiversity in the world. Until December 2017, the total Indonesian forest cover was about 120.6 Mha, or about $63 \%$ of Indonesian land cover (MoEF 2018). However, the rate of deforestation and forest degradation is increasing rapidly, affecting the Indonesian position to the second-highest regarding deforestation (Margono et al. 2014), including in Sumatra. The main causes of deforestation in Sumatra are agricultural and plantation expansion, wood extraction, as well as forest fires (Sloan et al. 2017).

About 2 Mha of 24.3 Mha degraded area in Indonesia is inside conservation area. The function of such area is to conserve the diversity of fauna and flora and to protect regional life systems, for example, The Leuser Ecosystem Area (LEA). LEA is located in Aceh and Sumatera Province, Indonesia, with total area of about 2.6 Mha. LEA was designated to aim towards conservation, production, and protection areas against deforestation, and secondly as a national strategic area (NSA) to protect ecosystem services. This ecosystem is the largest conservation area in
Malesian forest that plays essential role in biodiversity and ecosystem services conservation efforts. A part of LEA belongs to the World Heritage Site with danger status since 2011. It is the last habitat on earth where Sumatran tigers, elephants, orangutans, and rhinoceros are found together. Subsequently, LEA has high potency for the development of ecosystem services. It is reportedly storing 1.5 billion tons of carbon and has great ecotourism development potential (Siburian 2006).

However, LEA faces many threats. In 2005, its forest cover reached 1,982,00 ha, and in 2009 it decreased to $1,946,000 \mathrm{ha}$, the degraded forest area of LEA thus reached 36,000 ha during 2005-2009 due to deforestation. Infrastructure development also became one of threats in LEA, which has affected fragmentation and degradation (Suhendra et al. 2019). A half of road development was located in LEA's forests, and respectively in eight priority areas of conservation (Sloan et al. 2017), which influences forest management and biodiversity conservation planning decisions. In 2015, the Governor of Aceh issued a license to develop a palm oil plantation of approximately more than a thousand hectares in Subulussalam. This development led to land clearing in forest areas, 
specifically inside the LEA (Greenomics Indonesia 2015). According to Rainforest Action Network (2016), from January to September 2016, about 7,187 ha of forest and peatland in Aceh (amounting to 85\% of LEA) were degraded by clearance activity for oil palm plantation. As per said report, this industrial palm oil plantation has led to the death of more than $95 \%$ population of Sumatran orangutans. In achieving sustainable forest management (SFM), LEA authorities need to collaborate with all stakeholders, including the local communities. According to the data of Ministry of Environment and Forestry (2018), $34.1 \%$ of villages or about 25,800 villages in Indonesia area located surrounding the forest and very dependent on the forest resources, hence they have very essential roles to conserve biodiversity and achieve SFM.

However, Indonesian forests need assessment and monitoring systems to support the management of the ecosystem, including biodiversity conservation effectively, efficiently, and accurately. An important tool to support those managements is by using remote sensing. Remote sensing for those activities has high potency and a lot of vegetation indexes are used to indicate vegetation cover. One of them is commonly used, Normalized Difference Vegetation Index (NDVI) (Taufik et al. 2017; Hu et al. 2008), which aims to estimate land cover and vegetation changes.

Strengthening SFM can be achieved by conserving/ restoring biodiversity, collaborating with the local communities in biodiversity measurement, as well as considering social-economic, and ecological aspects. One way to accommodate those aspects is through the implementation of the agroforestry system. Agroforestry is a safeguarding way in bridging social, economic and ecological aspects. It is a dynamic landscape that has contributed to reduce deforestation and forest degradation and improve food security, ecosystem services, and livelihoods (Griggs et al. 2013; Minang et al. 2014). Agroforestry practices are well known to the local communities in Indonesia such as tembawang in West Kalimantan, umaq in East Kalimantan, talun in West Java (Hartoyo et al. 2018), and agroforestry of coffee in Aceh. According to Shibu and Sougata (2012), implementation of agroforestry organic coffee is to conserve/restore biodiversity and reduce chemical leaching to environment and emission of greenhouse gases compared to non-organic coffee (Shibu and Sougata 2012). Agroforestry systems conserve biodiversity due to there is species combination for plant integration such as combination coffee with tree shade. Tree shade can decrease the number of weeds, improve indigenous biodiversity by providing shade for the other species, and feeding for birds and insects.

However, vegetation cover data as an approach to monitor forest cover changes in LEA is still lacking. Furthermore, baseline data regarding composition, structure and vegetation diversity in LEA is very limited and needs to be enhanced as a strategy for biodiversity and sustainable forest management at the village level. The objectives of this study were to analyze vegetation cover using Normalized Difference Vegetation Index (NDVI) in
LEA and its relation to agroforestry structure, composition, and diversity in Agusen Village, Gayo Lues District, and Alur Durin Village, East Aceh District, Aceh Province which are located in LEA.

\section{MATERIALS AND METHODS}

\section{Study sites and period}

This study was conducted in the Leuser Ecosystem Area (LEA) of Aceh Province, Indonesia specifically in Agusen Village, Blangkejeren Sub-district, Gayo Lues District and Alur Durin Village, Serba Jadi Sub-district, East Aceh District. Analysis of vegetation cover in LEA, vegetation structure, composition and diversity measurements in agroforestry practices were carried out from October to December 2020. The map of study locations is presented in Figure 1.

In 1927, a local community proposed Alas Valley as a preservation area to the government of Dutch Hindia as a part of effort in reducing deforestation. Then, Dr. Van Heurn (the Dutch government) protected the area of Bukit Barisan, Singkil, and Tripa River in Meulaboh. In 1934, the local community declared Tapak Tuan that was signed by the Dutch East Indies government in maintaining the Leuser area. Based on the rule ZB No. 317/35, this area then was converted into Leuser Mountain Suaka Alam (142 800 ha). In 1980, Indonesian Ministry of Agriculture issued the Decree of the Ministry of Agriculture No. 69/Kpts/Um/II/1980 to establish Gunung Leuser National Park (792 675 ha). Afterward, Indonesian Ministry of Forestry (the Decree of the Ministry of Forestry No. 276/Kpts-II/1997) declared area of national park was 1094 692 ha in 1997. The UNESCO declared Gunung Leuser National Park (33\% of LEA) as the World Heritage Sites, specifically a Sumatran Tropical Rainforest group in 2014 (Rainforest Action Network 2016).

LEA consists of various ecosystems from sub-alpine, lowland dipterocarp and swamp (Gathorne-Hardy et al. 2001). Rafflesia and approximately $54 \%$ of animals in Sumatera are found in LEA. There are 382 birds, 105 mammals, 95 reptiles as well as amphibians. LEA is the last habitat for endangered species such as Sumatran orangutans, tigers, elephants, and rhinos that living together.

\section{Vegetation index analysis using Normalized Difference Vegetation Index (NDVI) in The Leuser Ecosystem area}

This study used spatial analysis to estimate vegetation cover in Leuser Ecosystem Area (LEA). We used Landsat 8 satellite imagery that could be accessed at U.S Geological Survey (https://earthexplorer.usgs.gov) and selected the best imageries with cloud cover $<20 \%$. The results of the imageries were in path rows: $129 / 57$ (dated 22 March 2020), 129/58 (dated 2 January 2020), 130/57 and 130/58 (date 13 March 2020). The data were re-projected to UTM coordinate system, WGS 84 and $47 \mathrm{~N}$. Vegetation index was analyzed by using NDVI, specifically band 4 and band 5 in Landsat 8. The formula as follows (Rouse et al. 1974; $\mathrm{Xu}$ and Guo 2014): 


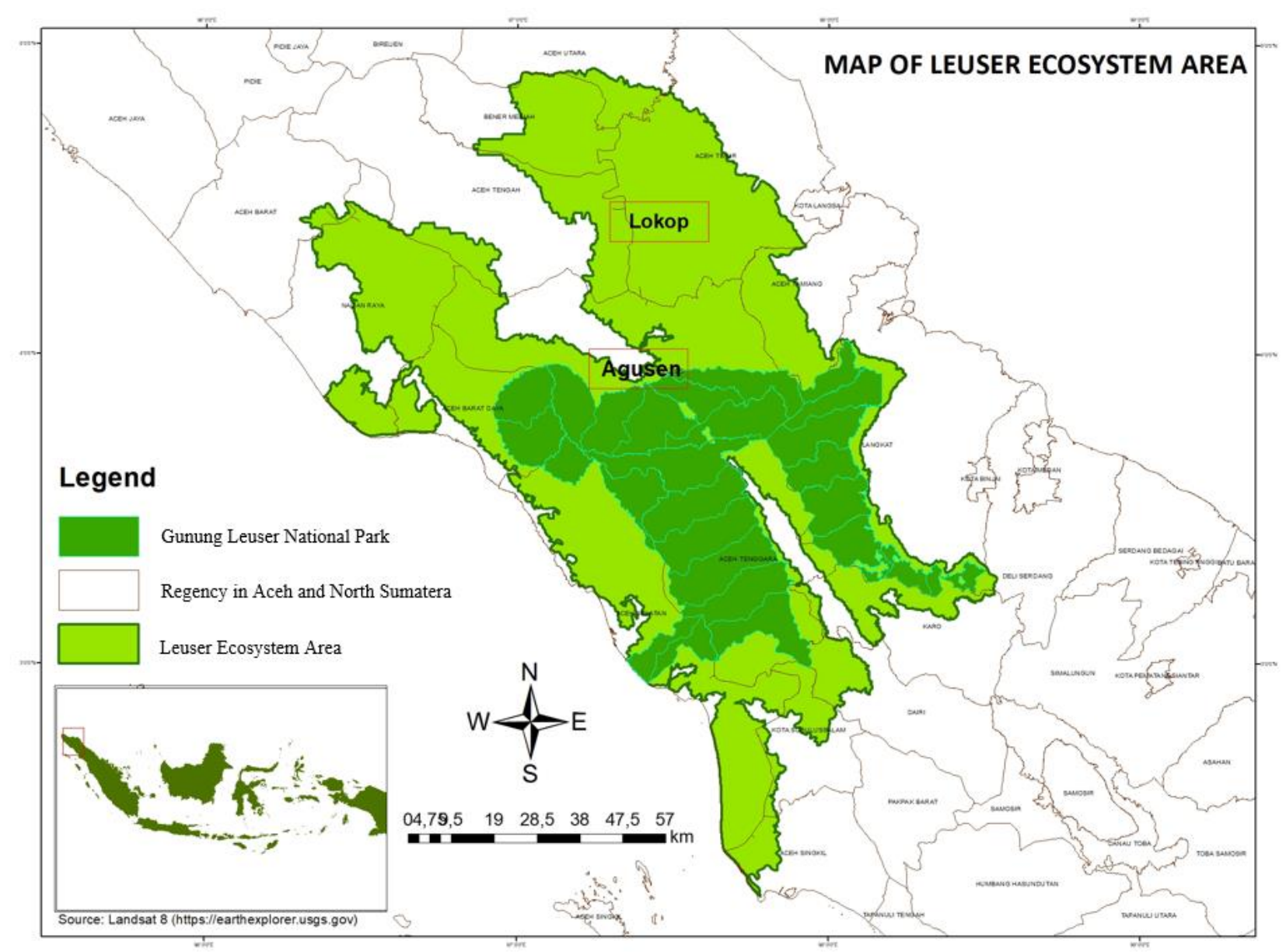

Figure 1. The map of research locations in Leuser Ecosystem Area (LEA), respectively in Agusen and Alur Durin Villages

$$
\begin{aligned}
& \mathrm{NDVI}={ }^{(\mathrm{NIR}-\mathrm{RED}) /(\mathrm{NIR}+\mathrm{RED})} \\
& \text { NDVI }={ }^{(\text {Band } 5-\text { Band } 4)} /(\text { Band } 5+\text { Band } 4)
\end{aligned}
$$

Landsat 8 used the combination of bands 5 (NIR), 4 (Red), and 3 (Green) for generating RGB color. NDVI was obtained by calculating near-infrared (NIR) and red light (RED) bands. The main steps for processing the imagery data using ArcGIS 10.3 were (i) the collection of satellite data (four scenes), (ii) image pre-processing consisting of compositing the bands, mosaicing and clipping the imageries to the spatial extent of LEA, (iii) geo-referencing data, (iv) determination of NDVI threshold, then (v) classification of vegetation density. Based on the NDVI analysis, LEA was classified into 5 classes, namely nonvegetation area, open area, water body (class 1 ), very low dense vegetation (class 2), low dense vegetation (class 3), moderately dense vegetation (class 4), and highly dense vegetation (class 5) (Table 1; Figures 2-3).

As reference data, we used canopy cover data 2018 in LEA based on land cover change monitoring system. This raw data is available at https://lulcc.ipb.ac.id. Canopy cover ranging from 0 to $100 \%$. A higher percentage of canopy cover indicated a denser canopy or forest in an ecosystem (Hudjimartsu et al. 2019). NDVI values ranging from-1 to 1. Therefore, we rescaled the values of NDVI in order to have the percentage between $0-100 \%$, and overlaid NDVI with canopy cover maps. NDVI consisted of 11 sample points for each class, hence there were 55 sample points. We distributed all sample points randomly, after the NDVI and canopy cover map was overlaid. Afterward, we calculated the accuracy and standard error.

Table 1. NDVI value and the greenness level of the vegetation (Wahyunto and Heryanto 2006)

\begin{tabular}{lll}
\hline $\begin{array}{l}\text { NDVI } \\
\text { class }\end{array}$ & $\begin{array}{l}\text { NDVI } \\
\text { value }\end{array}$ & The greenness level of the vegetation \\
\hline 1 & $<-0.03$ & $\begin{array}{l}\text { Non-vegetation area, open area, } \\
\text { waterbody }\end{array}$ \\
2 & $-0.03-0.15$ & $\begin{array}{l}\text { Very low dense vegetation } \\
\text { Low dense vegetation }\end{array}$ \\
3 & $0.15-0.25$ & $\begin{array}{l}\text { Moderately dense vegetation } \\
4\end{array}$ \\
5 & $0.26-0.35$ & Highly dense vegetation \\
\hline
\end{tabular}




\section{Sampling plot design}

This study used purposive sampling method to establish sampling plot. The criteria were the plot should implement agroforestry practice, owned by the local community, and well-accessed. Definition of agroforestry practices in this study followed definition of Lundgren (1982). Agroforestry is an integration of at least one woody species with other crops or plantations. Sampling plots were square with size $20 \mathrm{~m} \times 20 \mathrm{~m}$ for measuring tree level, then divided into subplot $10 \mathrm{~m} \times 10 \mathrm{~m}$ (pole level), $5 \mathrm{~m} \times 5 \mathrm{~m}$ (sapling level), and $2 \mathrm{~m} \times 2 \mathrm{~m}$ (understory and seedling level) (Sambas et al. 2018; Raharjeng et al. 2019). According to Almulqu et al. (2018) and Hartoyo et al. (2018), tree is defined as a stem that has reached diameter at breast height $(\mathrm{DBH})>20 \mathrm{~cm}$, while pole has $10 \leq \mathrm{DBH} \leq 20 \mathrm{~cm}$, sapling has DBH $<10$ $\mathrm{cm}$ and $1.5 \mathrm{~m}$ height, seedling and understory have $<1.5 \mathrm{~m}$ height.

\section{Agroforestry structure, composition, and diversity}

Vegetation structure was analyzed at understory, seedlings, saplings, poles, and trees level. According to Mueller-Dombois and Ellenberg 1974), importance value index (IVI) at tree and pole level can be calculated by adding up relative density (RD), relative frequency (RF), and relative dominance (RDo). While IVI at understory, seedling and sapling can be calculated by adding up RD and RF with the following formula.

$$
\begin{array}{ll}
\text { IVI (pole and tree level) } & =\mathrm{RD}+\mathrm{RF}+\mathrm{RDo} \\
\text { IVI (seedling and sapling) } & =\mathrm{RD}+\mathrm{RF}
\end{array}
$$

Where, relative density (RD), relative frequency (RF), and relative dominance (RDo) can be obtained by calculating this formula:

Density (D) $=\frac{\text { Size plot }}{\text { Relative Density }(\mathrm{RD})=}$
$\frac{\text { Number of individuals of the species }}{\text { Number of individuals of all species }} \times 100$

Frequency $(\mathrm{F})=\frac{\text { Number of plot where species found }}{\text { Total size plots }}$

Relative frequency $(\mathrm{RF})=\stackrel{\text { Number of occurence of the species }}{\text { Number of occurence of all species }} \times 100$

$$
\text { Dominance }(\mathrm{Dm})=\frac{\frac{\text { Total basal area of the species }}{\text { Total size plots }}}{\text {. }}
$$$$
\text { Relative dominance }(\mathrm{RDo})=\frac{\text { Total basal area of the species }}{\text { Total basal area of all species }} \times 100
$$

Components of diversity can be divided into diversity, richness, evenness and dominance indices. We analyzed those indices based on the level of growth, specifically understory, seedling, sapling, pole and tree levels. Diversity index $\left(\mathrm{H}^{\prime}\right)$ was analyzed by using Shannon formula (Magurran 1988). According to Michell (1995), the value of $\mathrm{H}^{\prime}<1.5$ indicates low diversity, $1.5 \leq \mathrm{H}^{\prime} \leq 3.5$ indicates moderate diversity, and $\mathrm{H}^{\prime}>3.5$ indicates high diversity. Species richness is total number of species in the community. Evenness index (E) is a level of individual's distribution per species. Odum (1996) categorized uneven distributed if the value of $\mathrm{E}$ was $<0.5$, moderately distributed if $0.5 \leq \mathrm{E} \leq 0.75$, and evenly distributed if $\mathrm{E} \geq$ 0.75. Dominance index (C) (Misra 1980) is the dominance of a species in a community and if $\mathrm{C}$ is close to 0 meaning there are no dominant species, while if $\mathrm{C}$ is close to 1 , it means that a dominant species dominate the community.

\section{RESULTS AND DISCUSSION}

\section{Vegetation cover analysis using Normalized Difference Vegetation Index (NDVI) in the Leuser Ecosystem Area}

LEA consists of various landscapes such as lowland, mountain, and sub-alpine forests, as well as peatlands. In 2015, total area of LEA reached 2.6 Mha with $87 \%$ is forest, and $13 \%$ is another land use (APL). LEA is habitat to 582 species of fauna, specifically $16 \%$ of reptiles and amphibians, $18 \%$ of mammals, and $66 \%$ of birds (Wilmar 2015). Some endangered species are found in LEA, hence the experts of conservation and ecology regard LEA as a place of irreplaceable biodiversity.

Remote sensing technologies have assisted to assess and monitor the dynamics of forest area as well as vegetation area quickly, economically and easily. A method to assess and monitor those areas is using Normalized Difference Vegetation Index (NDVI), which calculates the vegetation's greenness from satellite data, ranging its value from-1 to 1 . Negative value of NDVI describes that the area has no vegetation or water body, while positive value describes vegetated area. NDVI analysis results in 5 vegetation classes (Table 1; Figure 2). Those were non-vegetation area, open area, water body (class 1), very low dense vegetation (class 2), low dense vegetation (class 3), moderately dense vegetation (class 4), and highly dense vegetation (class 5). This classification is shown in Table 1.

As a preliminary survey, the field conditions of each NDVI class were also recorded. In Figure 3, class 1 NDVI shows very rare density and tends to grass growth only. While class 2 NDVI showed more shrubs and herbs. Class 1 to 5 showed an increase in vegetation density.

Based on the vegetation index analysis (Figure 4), the largest area in LEA was known to belong to class 5, meaning that the most area $(70.91 \%)$ in LEA was dominated by highly dense vegetation $(1,870,116.40 \mathrm{ha})$. Then it was followed by class 4/ moderately dense vegetation (360,042.03 ha), class 2/ very low dense vegetation (206,817.80 ha), class 3/ low dense vegetation (193,776.67 ha), and class 1/ non-vegetation (6,561.57 ha). It indicates that in general, the potency of vegetation density in LEA is still high, especially in Gunung Leuser National Park (GLNP) area. Approximately 30.58\% of LEA'S area belongs to Gunung Leuser National Park and $69.42 \%$ is buffer zone. LEA is an effective buffer not only for maintaining forest ecosystem, but also for increasing 
the local communities' welfare. The local communities around LEA have critical and strategic roles in maintaining LEA. In order to protect LEA, as well as to increase the local community's welfare, appropriate forest management such as agroforestry practice is necessary.

After distributed 55 sample points in the NDVI and canopy cover maps, the result showed that the highest and the lowest accuracy respectively were in NDVI class 3
$(88.73 \%)$ and NDVI class 1 (76.74\%). While the average accuracy and standard errors were $83.33 \%$ and 2.62 (Table 2 ). This error might be caused by cloud cover, and the differences in satellite imagery period used for NDVI analysis (2020) and canopy cover analysis (2018). During this gap period may occur conversion from a highly dense to moderately dense, even open area.
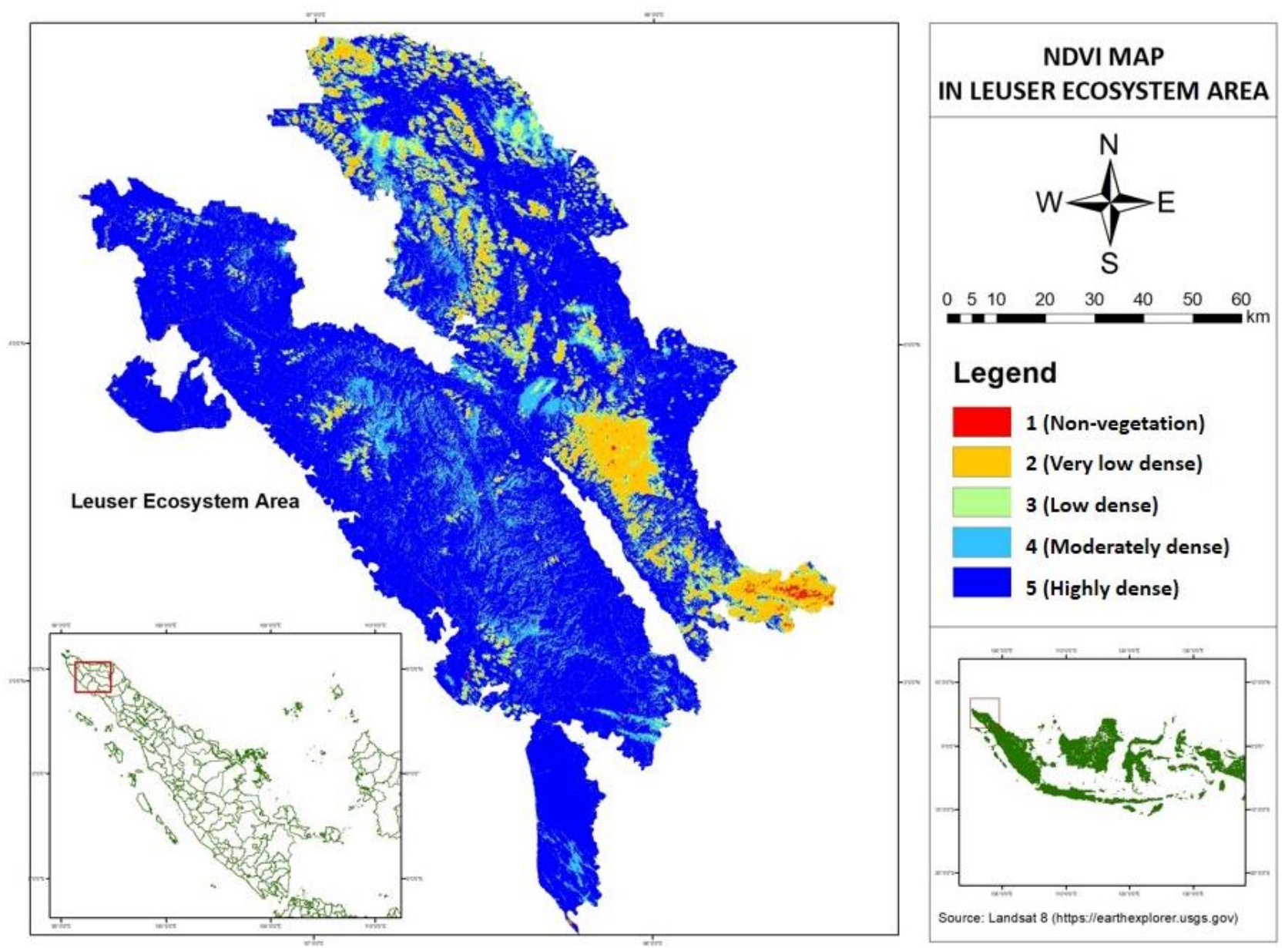

Figure 2. Map of NDVI in LEA on March 2020 from Landsat 8

Table 2. NDVI in LEA, accuracy and standard error

\begin{tabular}{cccccc}
\hline NDVI Class & NDVI value & NDVI value after rescaling (\%) & LEA (ha) & Accuracy (\%) & Standard Error \\
\hline 1 & $<-0.03$ & $34.53-57.38$ & 6561.57 & 76.74 & 4.01 \\
2 & $-0.03-0.15$ & $57.38-63.82$ & 206817.80 & 81.00 & 3.61 \\
3 & $0.15-0.25$ & $63.82-68.90$ & 193776.67 & 88.73 & 2.05 \\
4 & $0.26-0.35$ & $68.90-72.80$ & 360042.03 & 82.35 & 1.44 \\
5 & $0.35-0.61$ & $72.80-84.32$ & 1870116.40 & 87.84 & 2.01 \\
Average & & & & 83.33 & 2.62 \\
\hline
\end{tabular}




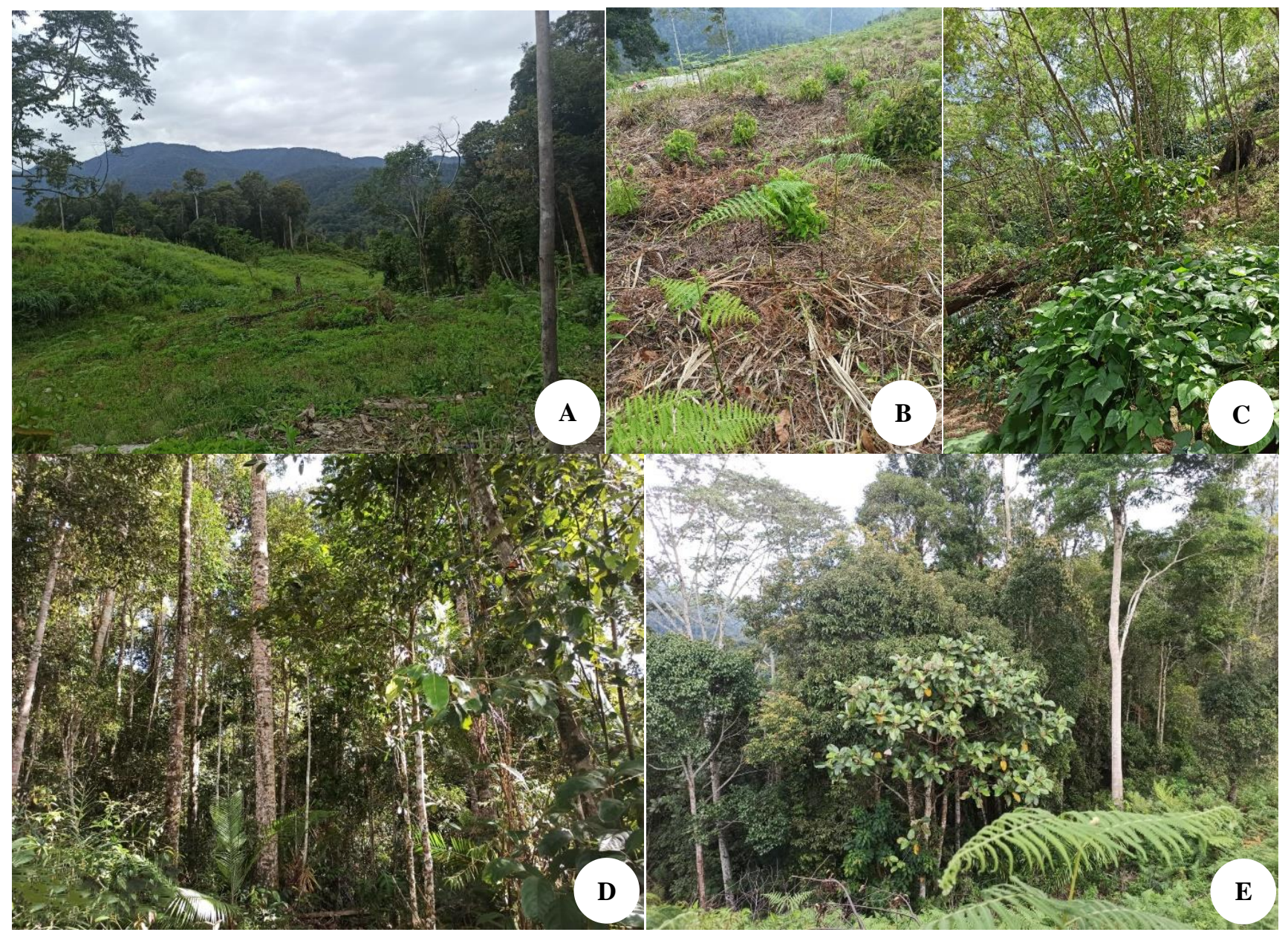

Figure 3. Field photographs of vegetation as per NDVI classification. A. Non-vegetation area, open area, water body; B. Very low dense vegetation; C. Low dense vegetation; D. Moderately dense vegetation; E. Highly dense vegetation

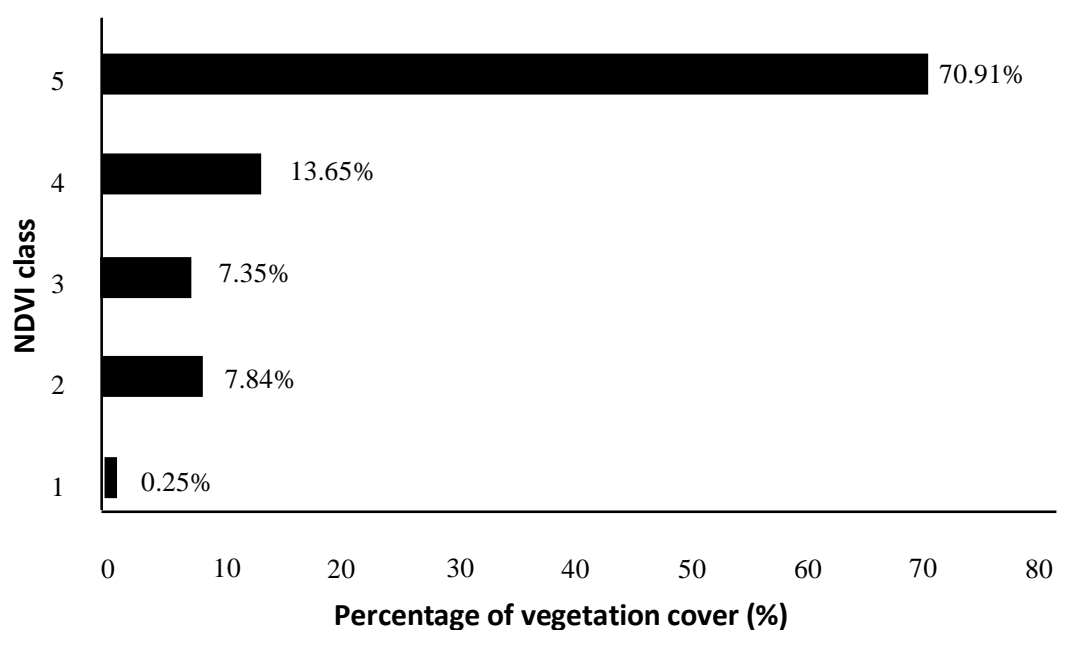

Figure 4. Percentage of vegetation cover in LEA 


\section{Agroforestry structure, composition, and diversity in Agusen Village, Blangkajeren Sub-district, Gayo Lues District, Aceh}

As the habitat functions, agroforestry systems support the habitat of flora and fauna. The habitat function can be measured by vegetation structure and composition, as well as diversity indices. Agroforestry practices have been recognized by the local community in Agusen Village, especially for shading of coffee (Coffea arabica) as a main commodity of agroforestry, as it adds to income of the local communities. This study also found other species to be incorporated in local agroforestry, such as candlenut or kemiri (Aleurites moluccanus), petai cina (Leucaena leucocephala), and cacao (Theobroma cacao).

Number of plants found in agroforestry practices in Agusen Village was 209 individuals or 1,045 individuals/ha. It consisted of seedlings (95 individuals), understory (32 individuals), saplings (43 individuals), poles (11 individuals) and trees (28 individuals) (Figure 5). This agroforestry structure has not resulted in reverse $\mathrm{J}$-curve. Vegetation structure with reverse J-curve shows natural forest structure. Some agroforestry practices, such as agroforest in East Kalimantan showed reverse J-curve tree structure (Hartoyo et al. 2018). It is similar to the structure of simpukng (forest garden) in East Kalimantan (Mulyoutami et al. 2009), which reported 21 species or 1,050 species per ha which included 5 species at seedling level, 9 each at understory, sapling and tree, while 3 at pole level.

Importance value index (IVI) is used for analyzing the role and dominance of a species in a specific ecosystem. A species that has high IVI results in higher species role in a community (Martono 2012). Petai cina (Leucaena leucocephala) dominated at seedling (110.76\%) and pole (239.25\%) levels in agroforestry practice in Agusen Village (Tables 3 and 4) and at these levels L. leucocephala can be found in almost all plots, showing that this species has high adaptability. L. leucocephala has been introduced in 120 countries with subtropical, tropical, and warm temperate, including in agroforestry system and other aims (Hughes 2006). This species belongs to Fabaceae family and has capability to do nitrogen fixation and therefore to increase soil fertility. This species grows well $1,500 \mathrm{~m}$ above sea level and can be used as a fence plant (Praja and Oktarlina 2017). The local communities in Agusen Village selected L. leucocephala as shading of coffee.

Coffee (Coffea arabica) dominated at sapling level (Table 3). Agusen Village is located $1000-1200 \mathrm{~m}$ asl and this altitude is suitable for coffee's growth. Gayo coffee is popular both locally, nationally and internationally. Besides coffee (C.arabica), coklat (Theobroma cacao) also has high economic value. The local communities usually sell those dried commodities in the price range of IDR 15,000$18,000 / \mathrm{kg}$. Kerpe belene (Paspalum dilatatum) which is a native grass from South America and has been introduced to sub-tropical and tropical areas was found to dominate at understory level (Table 3). At tree level, Kemiri (Aleurites moluccanus) was the most dominant (156.28\%) and was available in almost all plots (Table 4). Seeds of kemiri ( $A$. moluccanus) also can be used for making paper. The shading species for Coffee (C. Arabica) growth was petai cina (L. leucocephala), kemiri (A. moluccanus), and durin (Durio zibethinus).

Each vegetation also has a level of stability of species diversity that can be measured by determining several indices including diversity, dominance, and evenness indices. Those indices were calculated based on the classification of plant growth level, specifically understory, seedling, sapling, pole and tree levels. Based on Table 5, the highest of $\mathrm{H}^{\prime}$ value was at sapling level (1.29), and the lowest of $\mathrm{H}^{\prime}$ value was at pole level (0.47). At all level of growth, the diversity index $\left(\mathrm{H}^{\prime}\right)$ was classified into low diversity $\left(\mathrm{H}^{\prime}<1.5\right)$. Management of agroforestry system depends on the landowners or managers and their selection of shade tree species with high economic value Hartoyo et al. $(2018,2020)$ reported that the local communities select species in agroforestry practices depending upon socioeconomic aspects, site species matching, and market.

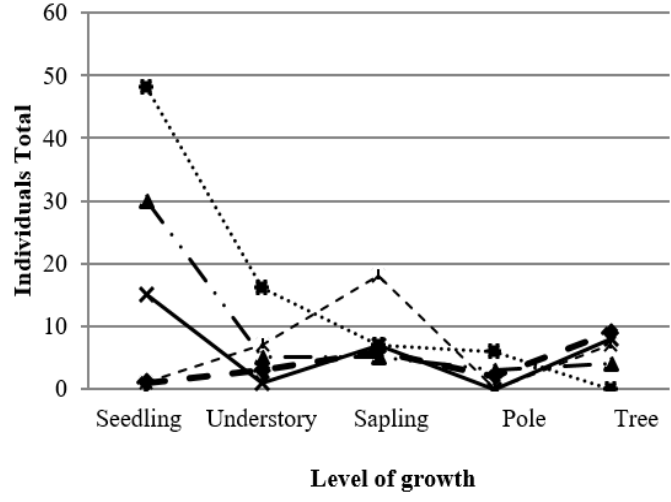

A

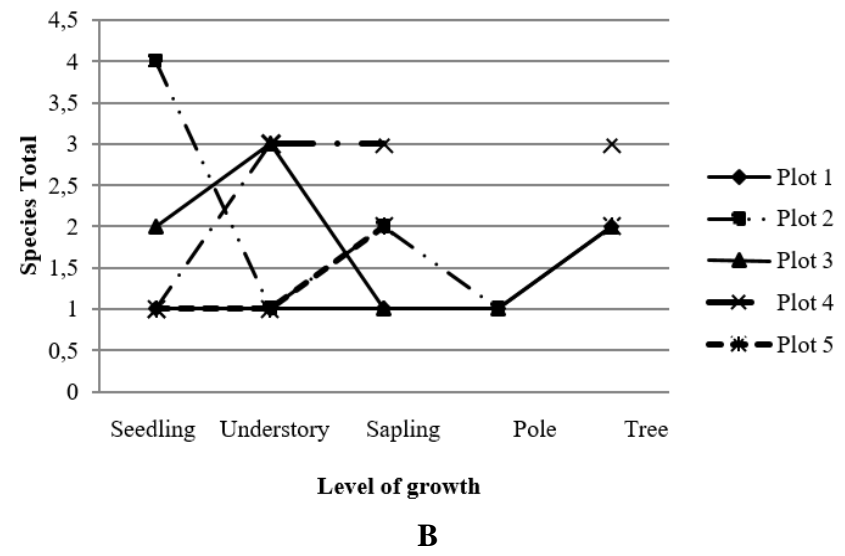

Figure 5. Individual (A) and species (B) total at each level growth in agroforestry in Agusen Village, Gayo Lues District, Aceh, Indonesia 
Dominance index (C) is used for measuring dominant species in an ecosystem. Misra (1980) classified C value from 0 to 1 . The analysis of $\mathrm{C}$ value revealed that dominant level of growth belonged to seedling $(\mathrm{C}=0.53)$ and pole levels $(\mathrm{C}=0.70)$. While evenness index was evenly distributed at all levels of growth $(\mathrm{E}=0.68-0.83)$, except at seedling level $(\mathrm{E}=0.50)$ which belonged to moderate distribution (Table 5). The highest $\mathrm{E}$ value indicated species sustainability in a community (Mawazin and Subiakto 2013).

Table 3. IVI of seedling level, understory level, and sapling level in Agusen Village, Gayo Lues District, Aceh, Indonesia

\begin{tabular}{|c|c|c|c|c|c|c|c|}
\hline \multirow{2}{*}{ Species (local name)/ IVI type } & \multirow{2}{*}{ Scientific name } & \multicolumn{5}{|c|}{ IVI (\%) } & \multirow{2}{*}{$\begin{array}{c}\text { IVI of } 5 \text { Plot } \\
(\%)\end{array}$} \\
\hline & & Plot 1 & Plot 2 & Plot 3 & Plot 4 & Plot 5 & \\
\hline \multicolumn{8}{|l|}{ IVI of seedling level } \\
\hline Gelime & Psidium guajava & 200 & - & - & - & - & 12.16 \\
\hline Petai cina & Leucaena leucocephala & - & 200 & 36.67 & 120 & 200 & 110.76 \\
\hline Kopi & Coffea arabica & - & - & 126.67 & - & - & 40.58 \\
\hline Tampu biasa & Macaranga tanarius & - & - & 36.67 & 40 & - & 24.33 \\
\hline Aren & Arenga pinnata & - & - & - & 40 & - & 12.16 \\
\hline \multicolumn{8}{|l|}{ IVI of understory level } \\
\hline Kerpe belene & Paspalum dilatatum & 200 & 68.75 & - & - & 200 & 86.46 \\
\hline Engop & Galinsoga parviflora & - & 56.25 & 110 & - & - & 47.22 \\
\hline Pakis minyak & Gymnocarpium robertianum & - & 31.25 & - & 200 & - & 28.47 \\
\hline Kekumil & Fargesia murielae & - & 43.75 & 90 & - & - & 37.85 \\
\hline \multicolumn{8}{|l|}{ IVI of sapling level } \\
\hline Coklat & Theobroma cacao & 200 & 78.57 & - & - & - & 44.44 \\
\hline Kopi & Coffea arabica & - & 121.43 & 200 & 79.49 & 133.33 & 94.44 \\
\hline Petai cina & Leucaena leucocephala & - & - & - & 41.03 & - & 13.89 \\
\hline Aren & Arenga pinnata & - & - & - & 79.49 & - & 27.78 \\
\hline Terong belanda & Solanum betaceum & - & - & - & - & 66.67 & 19.44 \\
\hline
\end{tabular}

Table 4. IVI of pole and tree level in Agusen Village, Gayo Lues District, Aceh, Indonesia

\begin{tabular}{|c|c|c|c|c|c|c|c|}
\hline \multirow{2}{*}{ Species (local name)/ IVI type } & \multirow{2}{*}{ Scientific name } & \multicolumn{5}{|c|}{ IVI (\%) } & \multirow{2}{*}{$\begin{array}{c}\text { IVI of } 5 \text { Plot } \\
(\%)\end{array}$} \\
\hline & & Plot 1 & Plot 2 & Plot 3 & Plot 4 & Plot 5 & \\
\hline \multicolumn{8}{|l|}{ IVI of pole level } \\
\hline Coklat & Theobroma cacao & 300 & - & - & - & - & 60.75 \\
\hline Petai cina & Leucaena leucocephala & - & 300 & 300 & - & - & 239.25 \\
\hline \multicolumn{8}{|l|}{ IVI of tree level } \\
\hline Kemiri & Aleurites moluccanus & 231.50 & - & 218.57 & 165.42 & - & 156.28 \\
\hline Petai cina & Leucaena leucocephala & 68.50 & - & 81.43 & - & 69.58 & 49,34 \\
\hline Pokat & Persea americana & - & - & - & 72.43 & - & 21,95 \\
\hline Dedep & Erythrina subumbrans & - & - & - & 62.15 & - & 18,79 \\
\hline Durin & Durio zibethinus & - & - & - & - & 230.42 & 53,63 \\
\hline
\end{tabular}

Tabel 5. Component of diversity indices in agroforestry practices in Agusen Village, Gayo Lues District, Aceh, Indonesia

\begin{tabular}{|c|c|c|c|c|c|c|}
\hline Level of growth & & $\mathbf{H}^{\prime}$ & & $\mathrm{C}$ & & $\mathbf{E}$ \\
\hline Seedling & 0.81 & Low & 0.53 & Dominant & 0.50 & Moderately distributed \\
\hline Understory & 1.15 & Low & 0.37 & Not dominant & 0.83 & Evenly distributed \\
\hline Sapling & 1.29 & Low & 0.33 & Not dominant & 0.80 & Evenly distributed \\
\hline Pole & 0.47 & Low & 0.70 & Dominant & 0.68 & Evenly distributed \\
\hline Tree & 1.11 & Low & 0.43 & Not dominant & 0.69 & Evenly distributed \\
\hline
\end{tabular}

Note: H': Shannon diversity index, C: Dominance index, E: Evenness index 


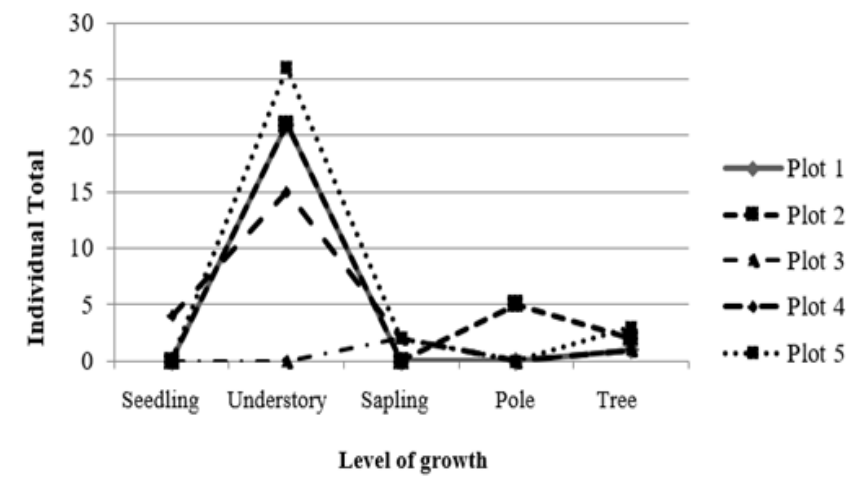

$\mathbf{A}$

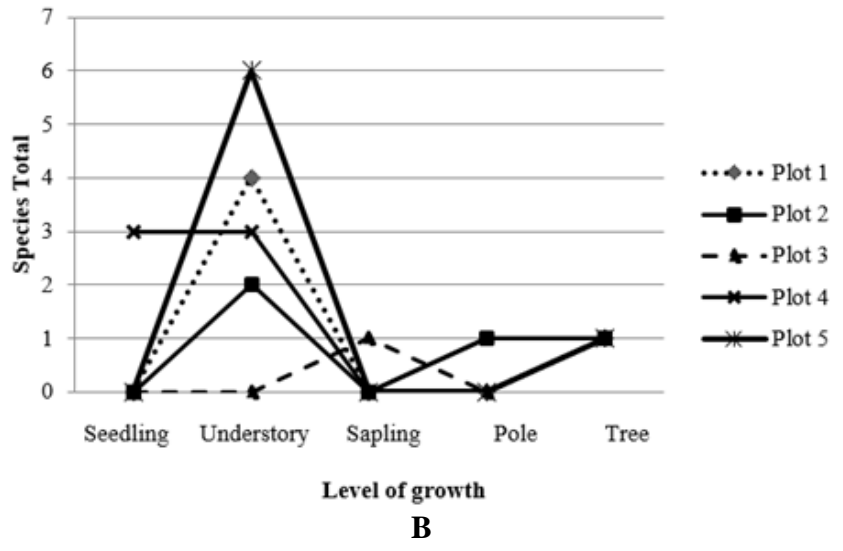

Figure 6. Individual (A) and species (B) total at each level growth in agroforestry in Alur Durin Village, East Aceh District, Aceh, Indonesia

\section{Agroforestry structure, composition, and diversity in Alur Durin Village, Serbajadi Sub-district, East Aceh District, Aceh}

Agroforestry species found in Alur Durin Village, Serbajadi Sub-district, East Aceh District were areca nut, banana, and some rubber, chocolate, and durian. Figure 6 shows the number of individuals and species of vegetation at the growth level. The growth level included seedlings, understory, sapling, pole, and tree.

The highest species at seedlings level were found in plot 4 (3 species), then the highest understory number of species were found in plot 5 (6 species). Sapling growth was found in two plots namely plots 3 and 4 . At pole level, the highest number of species was found in plot 2, while highest number of species was found in plot 5 .

There were two plots that showed the growth of vegetation in line with reverse-J curve (plots 4 and 5), meaning that those plots had normal vegetation growth such as in case of unmanaged forests. $J$ curve is shown by the number of individuals in the understory or seedlings phase more than the sapling, pole, or tree (Saputra et al. 2016). Reverse-J curve then needs to be considered by measuring the composition of vegetation in agroforestry. Vegetation composition can provide information related to the composition and shape of vegetation from plants included in the measurement plot (Sosilawaty 2020). The composition of vegetation can be seen through the calculation of IVI values.

Based on Table 6 , the highest IVI of understory level value is shown by Beke uten or furry harendong (Clidemia hirta). C. hirta is an invasive plant from Mexico (North America) and South America (Caribbean and tropical areas) that is aggressive due to its rapid seed germination, and this plant is capable of growing in every place such as landslides, roadsides, forests and under canopy shade (Nursanti and Adriadi 2018). The results of interviews with the Alur Durin village community mentioned that $C$. hirta is one of the plants that can be consumed. Firison et al. (2018) has also indicated wound healing property of $C$. hirta.

Table 7 shows that seedlings levels are only found in plot 4. The highest IVI showed by oil palm (Elaeis guineensis) is $83.33 \%$. The existence of oil palm as plantation agriculture is well known throughout Indonesia, even being a plant from the agricultural sector that contributes the largest foreign exchange (Sinaga and Hendarto 2012), so it is natural that the existence of palm can be found easily. The next plants included in the seedlings are guava (Psidium guajava) and rambutan (Nephelium lappaceum), with an IVI score of $58.33 \%$ each. Both species of seedlings other than this palm just grow wild on the site, namely in plot 4 . The seedlings of guava and rambutan growing wild are thought to be carried by animals (excreta) or humans who consume the fruit of the plant, then leave the seeds in place. As Mudiana (2005) explained, animals such as birds, squirrels, mammals, or primates have a role in the dispersal of seeds that can grow into new individuals.

The sapling level was only found in two plots, namely the third and fourth plots, while pole level was only found in the second plot (Table 7). The species that belong to the level of the sapling is keruing and rubber. Each IVI owned by both species in the data values was $200 \%$. Rubber (Hevea brasiliensis) was found in mixed gardens, however, the presence of rubber in Serbajadi (East Aceh District) has decreased due to perceived lack of impact on the economic sector, and currently, rubber are being planned to be replaced with areca nut or banana. Only two individuals were found from as keruing (Dipterocarpus alatus).

The highest IVI value (159.94\%) in case of trees was shown by durian species (Durio zibethinus) (Table 7). The existence of durian in agroforestry land owned by the community has dominated for a long time, seen from the size of the tree that has been very large with $\mathrm{DBH}$ up to $45.54 \mathrm{~cm}$. Durian is deliberately not turned off or cut down by the people community because it adds to one of the seasonal incomes for the local community and it provides one of the ingredients for traditional food of the community called asamdurin. The tree with next highest IVI (55.63\%) is terap (Artocarpus elasticus) which is on plot 2, where as many as 2 individuals were found in close proximity.

Table 8 shows the index values of each calculated growth rate of the five data retrieval plots. Through the table, it can be known that the highest $H^{\prime}$ value is at the 
understory level with a value of 1.34 , which means that in the understory there was a high diversity of species in this vegetation group, but still relatively low based on the classification by Magurran (1988). While, the lowest $\mathrm{H}^{\prime}$ value was at the growth rate of the pole with a value of 0 . The low value of $\mathrm{H}^{\prime}$ indicates that the arrangement of vegetation in agroforestry land of the people community in Serbajadi (East Aceh District) is overgrown by very few types of plants. Indriyanto (2015) mentioned that the higher the value of $\mathrm{H}^{\prime}$, the complexity and type of plants in vegetation is more diverse, and vice versa. Low $\mathrm{H}^{\prime}$ value may have been due to data collection at site with recent history of land clearing by spraying pesticides, so that many understorey and seedlings were dead at the time of survey, and only certain types of planted plants were present, as in case of plot 3 where there were very minimal plants underneath.

Dominance index $(\mathrm{C})$ indicated that the highest number was at the pole level with a value of 1 , meaning high dominance, while the lowest value was at the tree level with a value of 0.34 . Based on the conditions in the field, rubber stands grow regularly and close together in some gardens, only for adjusting to economic conditions, in future, some rubber growing areas may see areca nut as replacement in the future.

Furthermore, evenness index (E) showed the highest value $(0.95)$ was at the seedlings level. The lowest $E$ value (0) was at the pole level, while the other levels were noteven (0.3-0.35) moderately (0.56) distributed. This explained that the existence of the species present at the level of seedlings was distributed evenly.

Table 6. IVI of understory level in Alur Durin Village, East Aceh District, Aceh, Indonesia

\begin{tabular}{|c|c|c|c|c|c|c|c|}
\hline \multirow{2}{*}{ Species (local name) } & \multirow{2}{*}{ Scientific name } & \multicolumn{5}{|c|}{ IVI (\%) } & \multirow{2}{*}{$\begin{array}{c}\text { IVI of } 5 \text { Plot } \\
(\%)\end{array}$} \\
\hline & & Plot 1 & Plot 2 & Plot 3 & Plot 4 & Plot 5 & \\
\hline Beke uten & Clidemia hirta & 101.19 & 135.71 & - & 86.67 & - & 90.52 \\
\hline Beke & Melastoma affine & 29.76 & - & - & - & - & 7.87 \\
\hline Kerpe belene & Paspalum dilatatum & 29.76 & - & - & 66.67 & - & 20.56 \\
\hline Sesalit & unidentified & 39.29 & - & - & - & - & 10.28 \\
\hline Jih & Imperata cylindrica & - & 64.29 & - & - & - & 10.28 \\
\hline Semeje & Vitex trifolia & - & - & - & 46.67 & 20.51 & 16.95 \\
\hline Pelulut & Urena lobata & - & - & - & - & 20.51 & 7.87 \\
\hline Pecut kuda & Stachytarpheta jamaicensis & - & - & - & - & 24.36 & 9.08 \\
\hline Pang babi & Ageratum conyzoides & - & - & - & - & 20.51 & 7.87 \\
\hline Rumput gajah & Pennisetum purpureum & - & - & - & - & 55.13 & 18.71 \\
\hline
\end{tabular}

Table 7. IVI of seedling level, sapling level, pole level and tree level in Alur Durin Village, East Aceh District, Aceh, Indonesia

\begin{tabular}{|c|c|c|c|c|c|c|c|}
\hline \multirow{2}{*}{ Species (local name)/ IVI type } & \multirow{2}{*}{ Scientific name } & \multicolumn{5}{|c|}{ IVI (\%) } & \multirow{2}{*}{$\begin{array}{c}\text { IVI of } 5 \text { Plo } \\
(\%)\end{array}$} \\
\hline & & Plot 1 & Plot 2 & Plot 3 & Plot 4 & Plot 5 & \\
\hline \multicolumn{8}{|l|}{ IVI of seedling level } \\
\hline Gelime & Psidium guajava & - & - & - & 58.33 & - & 58.33 \\
\hline Ramuten & Nephelium lappaceum & - & - & - & 58.33 & - & 58.33 \\
\hline Sawit & Elaeis guineensis & - & - & - & 83.33 & - & 83.33 \\
\hline \multicolumn{8}{|l|}{ IVI of sapling level } \\
\hline Keruing daun besar & Dipterocarpus alatus & - & - & 200 & - & - & 200 \\
\hline Rambung & Hevea brasiliensis & - & - & - & 200 & - & 200 \\
\hline \multicolumn{8}{|l|}{ IVI of pole level } \\
\hline Rambung & Hevea brasiliensis & - & 200 & - & - & - & 200 \\
\hline \multicolumn{8}{|l|}{ IVI of tree level } \\
\hline Durin & Durio zibethinus & - & - & - & 300 & 299.74 & 159.94 \\
\hline Terap & Artocarpus elasticus & - & 300 & - & - & - & 55.63 \\
\hline Kempas & Koompassia excelsa & - & - & 300 & - & - & 43.99 \\
\hline Rambung & Hevea brasiliensis & 300 & - & - & - & - & 40.44 \\
\hline
\end{tabular}

Tabel 8. Component of diversity indices in agroforestry practices in Alur Durin Village, East Aceh District, Aceh, Indonesia

\begin{tabular}{|c|c|c|c|c|c|c|}
\hline \multicolumn{2}{|l|}{ Level of growth } & \multirow{2}{*}{$\frac{\mathbf{H}^{\prime}}{\text { Low }}$} & \multicolumn{2}{|r|}{$\mathbf{C}$} & \multicolumn{2}{|r|}{$\mathbf{E}$} \\
\hline Seedling & 1.04 & & 0.38 & Not Dominant & 0.95 & Evenly distributed \\
\hline Understory & 1.34 & Low & 0.43 & Not Dominant & 0.56 & Moderately distributed \\
\hline Sapling & 0.69 & Low & 0.5 & Dominant & 0.35 & Not-evenly distributed \\
\hline Pole & 0 & Low & 1 & Dominant & 0 & Not-evenly distributed \\
\hline Tree & 1.21 & Low & 0.34 & Not Dominant & 0.3 & Not-evenly distributed \\
\hline
\end{tabular}

Note: H': Shannon diversity index, C: Dominance index, E: Evenness index 
To conclude, NDVI analysis of study area resulted in 5 vegetation classes including non-vegetation area, open area, water body (class 1), very low dense vegetation (class 2), low dense vegetation (class 3), moderately dense vegetation (class 4) and highly dense vegetation (class 5). The largest area in Leuser Ecosystem Are (LEA) belonged to class 5, meaning that most LEA areas were dominated by high dense vegetation $(1,870,116.40 \mathrm{ha})$. The average accuracy and standard error of NDVI analysis were $83.33 \%$ and 2.62 .

Agroforestry structures in agroforestry practices, both in Agusen Village and Alur Durin Village did not reflect reverse-J curve. It means that enrichment planting for increasing number of individuals and species is necessary. At all levels of growth in agroforestry practices in Agusen Village and Alur Durin Village, the diversity index (H') was classified into low diversity. While agroforestry practices in Agusen Village and Alur Durin Village showed no-dominant species, and most of the growth levels were evenly distributed.

Management of agroforestry system depends on the landowners or managers. They select the species that have high economic value, site species matching, and market. For example, C. arabica, $T$. cacao with A. moluccanus, $L$. leucocephala, $H$. brasiliensis, D. zibethinus as shading trees. Trees that produce non-timber products is an alternative way for conservation strategy and sustainable utilization.

\section{ACKNOWLEDGEMENTS}

The authors would like to thank Ministry of Research Technology and Higher Education, Republic of Indonesia for the funding, and Gunung Leuser National Park Management, as well as Forum Konservasi Leuser for assisting in this study.

\section{REFERENCES}

Almulqu AA, Arpornpong N, Boonyanuphap J. 2018. Tree species composition and structure of dry forest in Mutis Timau Protected Forest Management Unit of East Nusa Tenggara, Indonesia. Biodiversitas 19 (2): 496-503.

Firison J, Ishak A, Hidayat T. 2018. Pemanfaatan tumbuhan bawah pada tegakan kelapa sawit oleh masyarakat lokal (kasus di Desa Kungkai Baru, Kecamatan Air Periukan, Kabupaten Seluma-Bengkulu). AGRITEPA Jurnal Ilmu dan Teknologi Pertanian 5: 19-31. DOI 10.37676/agritepa.v5i2.776. [Indonesian]

Greenomics. 2015. Responses to operation of new palm oil concession in the Leuser Ecosystem. http://www.greenomics.org/docs/IPOP_Implementation_Report08_Greenomics.pdf

Griggs D, Stafford-Smith M, Gaffney O, Rockström J, Ohman MC, Shyamsundar P, Steffen W, Glaser G, Kanie N, Noble I. 2013 Policy: Sustainable development goals for people and planet. Nature 495 (7441): 305-307. DOI: 10.1038/495305a.

Gathorne-Hardy F, Syaukani, Eggleton P. 2001. The effects of altitude and rainfall on the composition of the termites (Isoptera) of the Leuser Ecosystem (Sumatra, Indonesia). J Trop Ecol 17: 379-393. DOI: $10.1017 / \mathrm{S} 0266467401001262$.

Hartoyo APP, Supriyanto, Siregar IZ, Theilade I, Prasetyo LB. 2018. Agroforest diversity and ethnobotanical aspects in two villages of
Berau, East Kalimantan, Indonesia. Biodiversitas J Biol Divers 19 (2): 387-398. DOI: 10.13057/biodiv/d190205.

Hartoyo APP, Karimatunnisa TA, Ikhfan AN, Wijayanto N, Azizah S. 2020. Vegetation structure, composition and diversity in agroforestry system in Andongrejo Village, Jember Regency, East Java. IOP Conf. Series: Earth Environ Sci 449 (2020) 012017.

Hu Y, Ban Y, Zhang Q, Hu Y, Liu J, Zhuang D. 2008. Spatial-temporal pattern of gimms NDVI and its dynamics in Mongolian Plateau. International Workshop on Earth Observation and Remote Sensing Applications, Beijing: IEEE, 1-6.

Hudjimartsu S, Tampinongkol F, Rudianto Y, Setiawan Y, Prasetyo LB. 2019. Canopy cover estimation based on support vector regression derived from Lidar \& Landsat 8 OLI. The 40th Asian Conference on Remote Sensing (ACRS 2019). Daejon. https://a-a-rs.org/proceeding/ACRS2019.

Hughes CE. 2006. Leucaena leucocephala. In: Invasive Species Specialist Group (ISSG) (Eds) Global Invasive Species Database. http://www.issg.org/. Accessed on 6.12.2020.

Indriyanto. 2015. Ekologi Hutan. PT BumiAksara, Jakarta, Indonesia. [Indonesian]

Lundgren BO. 1982. Cited in Editorial: What is Agroforestry? Agrofor Syst 1: 7-12.

Magurran AE. 1988. Measuring Biological Diversity. TJ International, Padstow, Cornwall, UK.

Margono BA, Potapov PV, Turubanova S, Stolle F, Hansen MC. 2014. Primary forest cover loss in Indonesia over 2000-2012. Nat Cli Change 4: 730-735. DOI: 10.1038/NCLIMATE2277.

Martono DS. 2012. Analisis vegetasi dan analisis jenis-jenis pohon utama penyusun hutan tropis dataran rendah di Taman Nasional Gunung Rinjani. Agritek 13 (2): 18-27. [Indonesian]

Mawazin, Subiakto A. 2013. Species diversity and composition of logged over peat swamp forest in Riau. For Rehabil J 1 (1): 59-73.

Michell P. 1995. Metode Ekologi untuk Penelitian Lapangan dan Laboratorium. UI Press. Jakarta, Indonesia. [Indonesian]

Minang PA, Duguma LA, Bernard F, Mertz O, van Noordwijk M. 2014. Prospects for agroforestry in REDD+ landscapes in Africa. Curr Opin Environ Sustain 6: 78-82. DOI: 10.1016/j.cosust.2013.10.015

Ministry of Environment and Forestry Republic of Indonesia [MoEF]. 2018. The State of Indonesia's Forests 2018. Ministry of Environment and Forestry, Republic of Indonesia. Jakarta, Indonesia. [Indonesian]

Misra KC 1980 Manual of Plant Ecology. 2nd ed. Oxford \& IBH Publishing Co., New Delhi, India.

Mudiana D. 2005. Pemencaran Syzygium cormiflorum (F. Muell.) B. Hyland. di sekitar pohon induk dalam Cagar Alam Lamedae, Kolaka, Sulawesi Tenggara. Biodiversitas J Biol Divers 6 (2): 129-132. DOI: 10.13057/biodiv/d060212

Mueller-Dombois D, Ellenberg H. 1974. Aims and Methods of Vegetation Ecology. John Wiley \& Sons, Canada.

Mulyoutami E, Rismawan R, Joshi L. 2009. Local knowledge and management of simpukng (forest gardens) among the Dayak people in East Kalimantan, Indonesia. For Ecol Manag 257 (2009): 20542061.

Nursanti, Adriadi A. 2018. Keanekaragaman tumbuhan invasif di kawasan Taman Hutan Raya Sultan Thaha Saifuddin, Jambi. Media Konservasi 28: 85-91. [Indonesian]

Odum EP. 1996. Dasar-dasar Ekologi. Universitas Gajah Mada Press, Yogyakarta, Indonesia. [Indonesian]

Praja MH, Oktarlina RZ. 2017. Uji efektivitas daun Petai Cina (Laucaena glauca) sebagai antiinflamasi dalam pengobatan luka bengkak. Majority 6: 60-63. [Indonesian]

Raharjeng ARP, Noviyanti D, Apriana E, Fahriati L, Hastati YD. 2019. Plant diversity on protected forest vegetation of Dempo Mountains, Pagar Alam, South Sumatera. Jurnal Biota 5 (1): 42-47.

Rainforest Action Network. 2016. Exposing the threats to the Leuser Ecosystem. San Fransisco, CA 94108.

Rouse JW, Haas RA, Schell JA, Deering DW. 1974. Monitoring the vernal advancement and retrogradation (green wave effect) of natural vegetation. NASA/GSFC Type III Final Report, Greenbelt, Md 371.

Sambas EN, Kusmana C, Prasetyo LB, Partomihardjo T. 2018. Vegetation analysis and population structure of plants at Mount Endut forested area, Gunung Halimun Salak National Park, Banten, Java, Indonesia. Reinwardtia 17 (1): 39-53.

Saputra AD, Indriyanto, Duryat. 2016. Composition, structure, and diversity of vegetation types in waterfall Wiyono Atas Wan Abdul 
Rachman grand forest park. Jurnal Sylva Lestari 4 (3): 83-96. [Indonesian]

Shibu J, Sougata B. 2012. Agroforestry for biomass production and carbon sequestration: an overview. Agrofor Syst 86 (2): 105-111.

Siburian R. 2006. Pengelolaan Taman Nasional Gunung Leuser bagian Bukit Lawang berbasis ekowisata. J Masyarakat dan Budaya 8: 67-90. [Indonesian]

Sinaga DM, Hendarto M. 2012. Analisis kebijakan pengelolaan perkebunan kelapa sawit di Provinsi Sumatra Utara. Diponegoro J Econ 1: 1-13. [Indonesian]

Sloan S, Locatelli B, Wooster MJ, Gaveau DLA. 2017. Fire activity in Borneo driven by industrial land conversion and drought during $\mathrm{El}$ Niño periods, 1982-2010. Glob Environ Chang 47: 95-109. DOI: 10.1016/j.gloenvcha.2017.10.001.

Sosilawaty M. 2020. Identifying the diversity of orchids in the Sebangau National Park in Central Kalimantan. Intl J Adv Res Eng Technol 11 (3): $185-191$
Taufik A, Ahmad SSS, Ahmad A. 2017. Classification of Landsat 8 satellite data using NDVI Thresholds. J Telecommun Electron Comput Engineer 8: 37-40.

Suhendra D, Yahya A, Faisal, Suhaimi, Syarifuddin. 2019. How Effective is the Environmental Law for the Conservation of the Leuser Ecosystem Area in Indonesia?. Advances in Social Science, Education and Humanities Research 413. Atlantis Press, New York.

Wahyunto W, Heryanto B. 2006. Pendugaan produktivitas tanaman padi sawah melalui analisis citra satelit. Informatika Pertanian. 15: 853869. [Indonesian]

Wilmar. 2015. Progress in Leuser Ecosystem: sustainability brief. www.wilmar-international.com

Xu D, Guo X. 2014. Compare NDVI Extracted from Landsat 8 Imagery with that from Landsat 7 Imagery. Am J Remote Sens 2 (2): 10-14. DOI: $10.11648 /$ j.ajrs.20140202.11. 